\title{
Biomarkers of pollution effects in the bivalves Mytilus edulis and Macoma balthica collected from the southern coast of Finland (Baltic Sea)
}

\author{
Kari K. Lehtonen ${ }^{1, *}$, Sari Leiniö ${ }^{1}$, Rolf Schneider ${ }^{2}$, Mirja Leivuori ${ }^{1}$ \\ ${ }^{1}$ Finnish Institute of Marine Research, PO Box 2, 00561, Helsinki, Finland \\ ${ }^{2}$ Baltic Sea Research Institute, Department of Biological Oceanography, Seestrasse 15, 18119 Rostock-Warnemünde, \\ Germany
}

\begin{abstract}
Levels of selected biomarkers in 2 bivalve species, the hard-bottom filter-feeder Mytilus edulis and the infaunal deposit/suspension-feeder Macoma balthica were measured in 2 areas (Tvärminne and Turku Archipelago) in the southern coast of Finland. The bivalves were collected for the measurement of acetylcholinesterase (AChE), glutathione-S-transferase (GST) and catalase (CAT) activities, and for the determination of metallothionein (MT) content. The content of organochlorines (8 PCB congeners, DDE, DDD, DDT, HCH, HCB, dieldrin) and selected heavy metals (Cd, Cu, Hg, $\mathrm{Zn}$ ) were measured in the soft tissues. In $M$. balthica collected from the Turku Archipelago region, biomarker gradients were observed in MT, GST and CAT, mostly coinciding with the tissue concentrations of total PCBs, DDTs and selected metals. In $M$. edulis the biomarker responses were less consistent with regard to tissue pollutant concentrations. In the Tvärminne region no marked biomarker gradients were observed. The levels of all biomarkers varied significantly between the two species. The integrated biomarker response (IBR) index showed good accordance with the observed high tissue levels of organochlorines at the northern Airisto station in both species. This study is the first of its kind performed in the coastal waters of Finland, and the results clearly demonstrate the usefulness of the multibiomarker approach. Moreover, the use of 2 sessile species with markedly differing feeding modes and living habitats is considered a rational strategy for assessing the pollution status of coastal sea areas.
\end{abstract}

KEY WORDS: Biomarkers · Baltic Sea · Bivalves · Macoma balthica $\cdot$ Mytilus edulis $\cdot$ Organochlorines $\cdot$ Heavy metals

\section{INTRODUCTION}

Assessment and monitoring of the state of contamination of the marine environment has traditionally been almost entirely based on measurements of concentrations of well-known harmful substances in seawater, sediments and/or biota. However, with the currently enormous and continuously increasing number of potentially toxic substances present in and released into world seas, this approach alone can no longer be considered practical, cost-effective or even possible.
Besides the obvious technical and economical constraints, the most important fact is that by using merely chemical measurements the biological effects of both single pollutants and the combined effect of a number of compounds in marine organisms remain unresolved; therefore, the true environmental hazards of contamination are insufficiently assessed. During the past decades, molecular, biochemical, cytological, immunological and physiological techniques for the detection of effects of pollutants in marine organisms, the socalled biomarkers, have been under dynamic develop- 

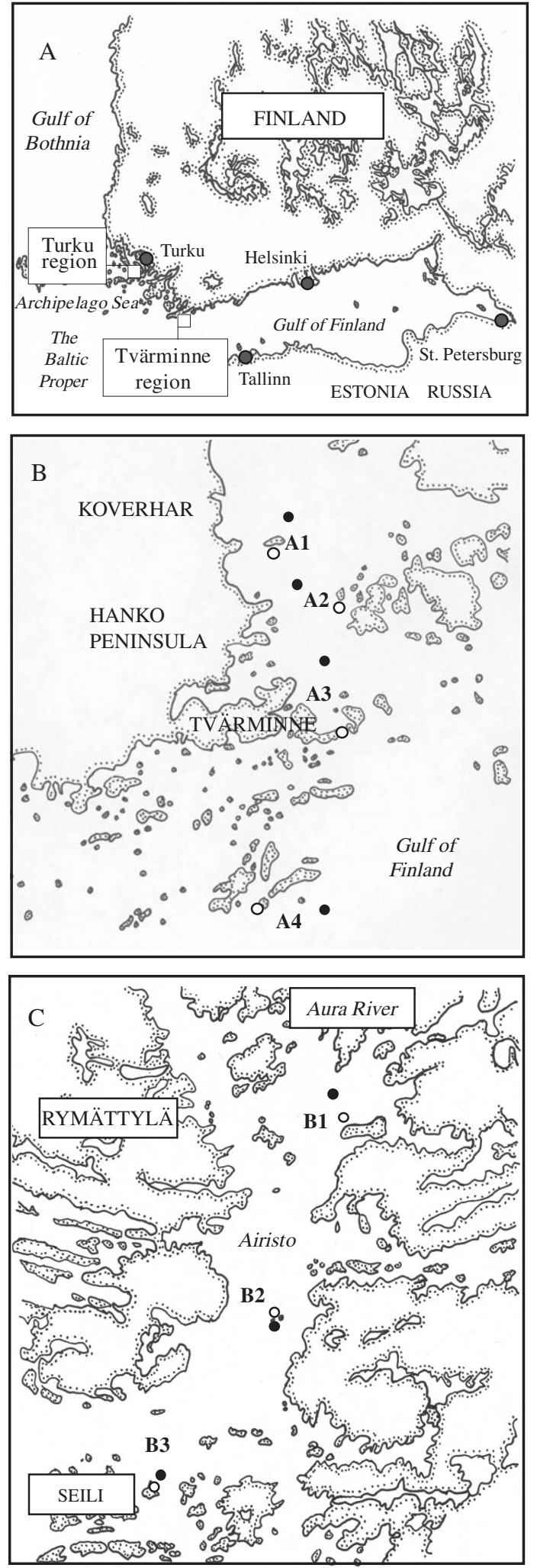

Fig. 1. Sampling stations of the present study. (A) Southern Finland and the Gulf of Finland, (B) Tvärminne Archipelago, (C) Turku Archipelago. O: Mytilus edulis stations; •: Macoma balthica stations ment. More recently, a strong emphasis on their further development and application in marine monitoring programmes has emerged within the European Union (e.g. OSPAR and MEDPOL related activities and the pan-European BEEP project [Biological Effects of Environmental Pollution on Marine Coastal Ecosystems, www.beep.u-bordeaux1.fr]). This topic needs urgent attention, particularly within the Baltic Sea area, where this approach has been largely neglected, e.g. in the HELCOM monitoring programme (Lehtonen \& Schiedek 2006).

Sessile benthic organisms are universally accepted as very suitable bioindicators of environmental contamination (e.g. Rainbow \& Phillips 1993). In the poor-diversity northern Baltic Sea, the hard-bottom filterfeeding mussel Mytilus edulis and the infaunal deposit/suspension-feeding clam Macoma balthica are among the very few benthic species available for environmental monitoring. The aims of the study were (1) to look at selected biomarkers in field conditions in bivalves from a northern Baltic Sea coastal marine environment with suspected pollution gradients; (2) to apply an integrated multibiomarker index; and (3) to compare the biomarker signals with concentrations of selected pollutants in the bivalve tissues. The nature of pollution in the investigated areas was largely unknown. Thus, biomarkers were chosen to represent different types of biological responses to elucidate the pollutant groups present in the environment that may cause effects. Of the selected biomarkers, acetylcholinesterase (AChE) activity is an indicator of synaptic neurotoxic effects (e.g. Day \& Scott 1990, Bocquené \& Galgani 1998); metallothionein (MT) content is used to indicate exposure to heavy metals (e.g. George \& Olsson 1994, Viarengo et al. 1999); glutathione-Stransferase (GST) is a Phase II enzyme involved in the detoxification of organic xenobiotics (e.g. Habig et al. 1974, Lee et al. 1988); and an increase in catalase (CAT) activity signifies oxidative stress caused by excessive oxyradical formation in the metabolism of various compounds (Claiborne 1985, Di Giulio et al. 1989).

\section{MATERIALS AND METHODS}

Sampling. Mytilus edulis and Macoma balthica were collected in 2 regions on the southern coast of Finland. In the archipelago area close to Tvärminne Zoological Station of the University of Helsinki (hereafter called 'Tvärminne region'), 4 sampling sites (A1 to A4) extending from the vicinity of the Koverhar steel factory towards the outer archipelago were sampled (Fig. 1). In the archipelago area close to the city of Turku ('Turku region') the 3-station sampling transect (B1 to B3) started from northern Airisto, close to a for- 
mer dumping site of harbour dredging waste, and ended in a presumably less-polluted area near the Archipelago Sea Research Station (on Seili Island). Because of habitat differences, the exact sampling locations of $M$. edulis and $M$. balthica differed slightly at each station, but together they represented a distinct area. Samples were taken in spring 2001, in the Turku region on 8 May and in the Tvärminne region on 15 to 17 May. $M$. edulis were collected by scuba diving, and M. balthica with the van Veen grab or by bottom trawling.

Hydrography. At the Macoma balthica stations, a water sample was obtained from ca. $1 \mathrm{~m}$ above the bottom and measured for dissolved oxygen concentration using the Winkler method (Grasshoff 1983) (Table 1). From the same sample, near-bottom temperature and salinity were measured with a YSI instrument. In connection with the sampling of Mytilus edulis, temperature and salinity were determined from the surface water $(1 \mathrm{~m})$. Water transparency was recorded using a Secchi disk (Tvärminne region) or estimating diving visibility (Turku region).

Sample preparation. For biomarker analyses, the bivalves collected from the Tvärminne region were dissected the same day as sampled. The specimens collected from the Turku region were kept overnight in a cold room $\left(6^{\circ} \mathrm{C}\right)$ in water buckets containing water from the sampling site, and they were dissected the next day. To minimise the differences in laboratory maintenance time, the dissecting of bivalve groups collected from different stations was always performed in the same order as the sampling in the field was done. Bivalves collected for pollutant analyses were kept overnight in ambient water for gut purging.

For AChE, gill pairs (Mytilus edulis) or foot tissue (Macoma balthica) from 5 individuals were pooled in 1 Eppendorf tube, with 10 tubes from each station. For MT, the digestive glands of 5 specimens were pooled in 1 tube, with 10 tubes per station. The digestive glands of 10 individuals were stored separately for the analysis of GST and CAT. Each sample was deposited in liquid nitrogen immediately after dissection and stored at $-80^{\circ} \mathrm{C}$ until analysis.

For pollutant analyses the bivalves were stored whole (with shells) at $-80^{\circ} \mathrm{C}$ until analysis. For heavy metal analyses 19 to 35 individuals were taken, while for the measurement of organochlorine levels the amount of specimens was up to 100, depending on the availability of animals. During dissection of soft bodies from the shells, all precautions were taken to avoid sample contamination. In 2 cases adequate numbers of bivalves could not be obtained for pollutant analyses.

Biomarker measurements. AChE activity: Analyses (6 replicates) were performed essentially as described in Bocquené \& Galgani (1998). Tissues were homogenised in 1:2 w/v 0.02 M phosphate buffer $(\mathrm{pH} 7.0)$ with $0.1 \%$ Triton X. Homogenates were centrifuged at $10000 \times g$ for $20 \mathrm{~min}$, and the supernatants (S9) were used for AChE measurement. A BioRad Benchmark 96-well microplate reader (BioRad) was used for the spectrophotometric determination of the Ellman reaction (Ellman et al. 1961). Tissue protein concentration was determined using the Bradford (1976) method, using bovine serum albumin (BSA) as the protein standard. AChE activity values are expressed as equivalents of acetylthiocholine (ACTC) hydrolysed (nmoles ACTC min $^{-1} \mathrm{mg}^{-1}$ protein), with 1 unit change in optical density $(\triangle \mathrm{OD})$ corresponding to the hydrolysis of $75 \mathrm{nmol}$ of ACTC.

MT content: Analyses (5 replicates) were carried out according to the method of Viarengo et al. (1997). Tissues were homogenised in reducing conditions (0.05 M sucrose TRIS buffer, pH 8.6, containing $0.01 \%$ $\beta$-mercaptoethanol). Homogenates were centrifuged at $30000 \times g$ for $20 \mathrm{~min}$. S9 were collected, and ethanol/chloroform fractionation was used to obtain the partially purified metalloprotein fraction. The MT concentration was then measured by spectrophotometric determination of - $\mathrm{SH}$ groups using Ellman's reagent (DTNB).

GST and CAT activity: Measurements were performed on 10 individuals from each study station,

Table 1. Hydrographic data recorded at the study stations during the sampling of Mytilus edulis and Macoma balthica. -: not measured

\begin{tabular}{|c|c|c|c|c|c|c|c|}
\hline $\begin{array}{l}\text { Station } \\
\text { code }\end{array}$ & $\begin{array}{l}\text { Station name: } \\
\text { M. balthica/M. edulis }\end{array}$ & $\begin{array}{l}\text { Date } \\
(2001)\end{array}$ & $\begin{array}{l}\text { Depth }(\mathrm{m}): M \text {. } \\
\text { balthica/M. edulis }\end{array}$ & $\begin{array}{c}\text { Temp. }\left({ }^{\circ} \mathrm{C}\right): \\
\text { bottom/surface }\end{array}$ & $\begin{array}{l}\text { Salinity (psu): } \\
\text { bottom/surface }\end{array}$ & $\begin{array}{l}\text { Secchi depth/ } \\
\text { visibility (m) }\end{array}$ & $\begin{array}{l}\mathrm{O}_{2}\left(\mathrm{ml} \mathrm{l}^{-1}\right) \\
\text { at bottom }\end{array}$ \\
\hline A1 & Koverhar & 15-17 May & $30 / 4$ & $4.2 / 7.7$ & $4.2 / 5.1$ & $3.5 /-$ & 6.55 \\
\hline $\mathrm{A} 2$ & Kummeli & 15-17 May & $32 / 5$ & $4.1 / 8.3$ & $5.6 / 5.0$ & $3.5 /-$ & 6.86 \\
\hline A3 & Storfjärden/Sundholmen & 15-16 May & $33 / 5$ & $4.4 / 7.6$ & $4.9 / 5.1$ & $4.0 /-$ & 6.24 \\
\hline A4 & Långskär/ Granbusken & 15-16 May & $36 / 4$ & $4.4 / 8.1$ & $6.2 / 5.1$ & $6.0 /-$ & 6.96 \\
\hline B1 & N. Airisto & 8 May & $23 / 2$ & $4.7 / 11.5$ & $5.7 / 4.9$ & $-/ 0.5$ & 9.27 \\
\hline B2 & Grangrundet & 8 May & $22 / 5$ & $5.2 / 9.1$ & $5.0 / 5.1$ & $-/ 1.0$ & 9.86 \\
\hline B3 & Högholmen & 8 May & $32 / 4$ & $4.8 / 7.8$ & $5.4 / 5.4$ & $-/ 1.5$ & 9.53 \\
\hline
\end{tabular}


determining both enzymatic rates from the same homogenate. Pieces of digestive gland (>15 mg) were homogenised (1:3 w/v) for 2 min in cold $100 \mathrm{mM}$ potassium phosphate buffer ( $\mathrm{pH}$ 7.0) using a Kontes pellet pestle. The homogenate was centrifuged at $10000 \times g$ for $20 \mathrm{~min}$. The S9 were diluted with cold buffer (see below) and kept on ice for analyses of enzyme activities, performed within $3 \mathrm{~h}$. The measurements were performed in a $1 \mathrm{~cm}$ quartz cuvette with total reaction volumes of 1275 (GST) and $1350 \mu \mathrm{l}$ (CAT) in buffer solution kept at room temperature $\left(20\right.$ to $\left.22^{\circ} \mathrm{C}\right)$.

The GST assay was performed using a modified method based on Habig et al. (1974). Dilutions of 1:10 (Mytilus edulis) and 1:40 (Macoma balthica) were prepared. $20 \mathrm{mM}$ chlorodinitrobenzene (CDNB) was used as the substrate and $20 \mathrm{mM}$ glutathione (GSH) as the co-substrate. GST activity was estimated by measuring the formation rate of conjugated substrate (CDNBGSH). CAT activity was measured as the disappearance rate of hydrogen superoxide $\left(\mathrm{H}_{2} \mathrm{O}_{2}\right)$ from the reaction solution according to Claiborne (1985). S9 dilutions of 1:10 (M. edulis) and 1:25 (M. balthica) were prepared for the test, and $\mathrm{H}_{2} \mathrm{O}_{2}$ was applied as a $60 \mathrm{mM}$ solution. All the reagents (except the buffer solution) were prepared daily immediately prior to the measurements.

Following addition of sample (supernatant) enzymatic reactions were monitored for 60 s using a PerkinElmer Lambda 2 spectrophotometer using the Timedrive mode of WinLab software. GST conjugates were measured at $340 \mathrm{~nm}$, and the reduction of $\mathrm{H}_{2} \mathrm{O}_{2}$ by catalase at $240 \mathrm{~nm}$. The reaction speed was afterwards evaluated between 0 and $30 \mathrm{~s}$, which showed a better linearity and slightly higher rates. Blank readings for spontaneous conjugate formation (GST) and $\mathrm{H}_{2} \mathrm{O}_{2}$ hydrolysation (CAT) were subtracted from the sample activity measurements. Protein in the S9 was determined on microplates using the Bradford (1976) method and a BSA standard.

Pollutant levels in tissues. Organochlorines: Before and after freeze-drying with a Christ-Alpha 1-4, the pooled samples of bivalve soft bodies were weighed to allow for calculations of wet-weight-based data. Samples were vigorously ground to a homogenous powder, from which lipids were extracted for $8 \mathrm{~h}$ in a Soxhlet apparatus using a mixture of $20 \%$ acetone in $n$ hexane. The extracts were concentrated in tared flasks using a rotary evaporator, and total lipids gravimetrically estimated. Clean-up and fractionation of organochlorine compounds were carried out by alumina and silica column chromatography within the guidelines of Holden \& Marsden (1969), and as specified by Schneider (1982). The gas chromatograph employed for the estimation of organochlorines was a FISONS instrument, GC 8000, equipped with an AS
800 auto-sampler for automatic on-column sample injection and an ECD 800 electron capture detector. It was fitted with a J\&W DB-35 $30 \mathrm{~m} \times 0.32 \mathrm{~mm}$ fused silica capillary column for separation and a J\&W $5 \mathrm{~m}$ $\times 0.53 \mathrm{~mm}$ untreated fused silica capillary column as a retention gap (pre-column). The carrier gas, hydrogen, was adjusted to a flow rate of $2 \mathrm{ml} \mathrm{min}^{-1}$ at $40^{\circ} \mathrm{C}$. $\mathrm{N}_{2}$ was used as detector make-up gas. The GC oven temperature programme was as follows: $1 \mathrm{~min} 40^{\circ} \mathrm{C}$ isothermal, $40^{\circ} \mathrm{C} \mathrm{min}^{-1}$ to $160^{\circ} \mathrm{C}, 10 \mathrm{~min}$ $160^{\circ} \mathrm{C}$ isothermal, $4^{\circ} \mathrm{C} \mathrm{m^{-1 }}$ to $290^{\circ} \mathrm{C}$ and $10 \min 290^{\circ} \mathrm{C}$ isothermal.

Mixed pesticide standard $(\alpha-, \beta-, \gamma-\mathrm{HCH}$, dieldrin, $o, p^{\prime}$ - and $p, p^{\prime}$-isomers of DDE, DDD and DDT) and PCB congener standard (PCB 52, 101, 105, 118, 138, 149,153 , and 180) solutions at (individual compound) concentrations of 5,10,15,20,50,100 and $150 \mathrm{pg} \mathrm{\mu l}^{-1}$ were applied for calibration. As an internal standard,

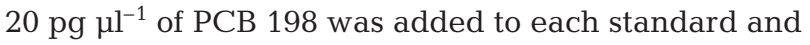
sample solution. The analytical quality of organochlorine estimation in bivalves was repeatedly checked by triplicate analysis of IAEA reference materials (IAEA 1980, 1988; copepod and mussel homogenates), resulting in typical standard deviations between 3 and $5 \%$, as well as by frequent participation in QUASIMEME laboratory performance studies.

Heavy metals: One pooled sample from each species and station was analysed for selected heavy metals $(\mathrm{Cd}, \mathrm{Cu}, \mathrm{Hg}$ and $\mathrm{Zn})$. The soft tissue was removed from the shells, refrozen and freeze-dried for $30 \mathrm{~h}$ with an Edwards Super Modulyo freeze dryer. Samples were homogenised in a Fritsch planetary mill (Pulverisette 5) with grinding bowls and balls made of zirconium oxide. Aliquots $(0.25 \mathrm{~g}$ ) were digested in Teflon bombs with $2 \mathrm{ml} \mathrm{H}_{2} \mathrm{O}$ and $5 \mathrm{ml} \mathrm{HNO}_{3}$ in a microwave oven. Samples were heated with pressure regulation at 150 psi for 60 min. After cooling, samples were diluted with Milli-Q water up to the $25 \mathrm{ml}$ mark in a volumetric plastic flask, transferred to plastic storage bottles and stored at room temperature until analysis. Heavymetal determinations were done with an atomic adsorption spectrophotometer (Perkin-Elmer AAS 5100 ZL). These measurements were made with the flameless method, with matrix modification and platform techniques. Commercial certified sediment reference materials BCR-422 and DORM-2 (NRCC) were used to control analytical reliability. For the elements studied, nearly $100 \%$ recoveries (80 to $110 \%$ ) were obtained for both reference materials.

Statistical treatment of data. Single-biomarker variability between the stations within each of the 2 study areas was investigated using a standard ANOVA and post-hoc Tukey's test. To study the relations between biological responses and tissue contaminant levels jointly in both species and study areas, the biomarker 
and tissue contaminant data from both species and study areas were combined by calculating normalised parameter values (between 0 and 1 ) for each species at each study station. The normalised values of single biomarkers or the sums of all 4 of them, now combined for both species, were analysed for linear regressions against normalised values of tissue levels of total organochlorines, $\Sigma$ PCBs, $\Sigma$ DDTs, single heavy metals or their sum recorded for both species. SYSTAT ${ }^{\mathrm{TM}} 9.0$ software was used for all statistical analyses.

To assess the 'pollution status' of each location, an integrated biomarker response (IBR) index was calculated for each species using all the 4 biomarkers studied. A simple starplot graphic tool (Microsoft Excel) was applied to the data to visualise the results. The IBR method of Beliaeff \& Burgeot (2002) is briefly described here. For each biomarker: (1) Calculation of mean and SD for each station. (2) Standardisation of data for each station: $x_{i}^{\prime}=\left(x_{i}-\right.$ mean $\left.x\right) / s$. Result: variance $=1$, mean $=0$. (3) Using standardised data, addition of the value obtained for each station to the absolute (= non-negative) value of the minimum value in the data set: $B=x_{i}^{\prime}+\left|x_{\min }\right|$. Result: adjusts the lowest value in the set to zero. For all the biomarkers treated this way: calculation of starplot areas by multiplication of the obtained value of each biomarker $\left(B_{i}\right)$ with the value of the next biomarker, arranged as a set, dividing each calculation by 2 and summing-up of all values: $\left\{\left[\left(B_{1} \times B_{2}\right) / 2\right]+\left[\left(B_{2} \times B_{3}\right) / 2\right]+\ldots+\left[\left(B_{n-1} \times\right.\right.\right.$ $\left.B_{n}\right) / 2$ ]\}. Result: IBR (average of different arrangements of biomarkers in the set).

Tissue concentrations of organochlorines and heavy metals were also standardised this way, to obtain indices for both total organochlorines and total heavy metal loads in the bivalve tissues at the different study stations. From all the standardised organochlorines and heavy metals, a mean value was calculated to represent the 'general load' of these pollutant groups at the different study stations.

\section{RESULTS}

\section{Spatial variability in biomarker responses}

\section{$\mathrm{AChE}$}

In both bivalve species, AChE activities were relatively homogenous over the regions and stations, and no significant differences could be noted (Fig. 2, Table 2). In the gill tissue of Mytilus edulis the AChE activity ranged from 19.3 to $25.9 \mathrm{nmol}$ ACTC min ${ }^{-1}$ $\mathrm{mg}^{-1}$ protein, being lower in the foot tissue of Macoma balthica with values between 17.7 and $21.8 \mathrm{nmol}$ ACTC $\mathrm{min}^{-1} \mathrm{mg}^{-1}$ protein.

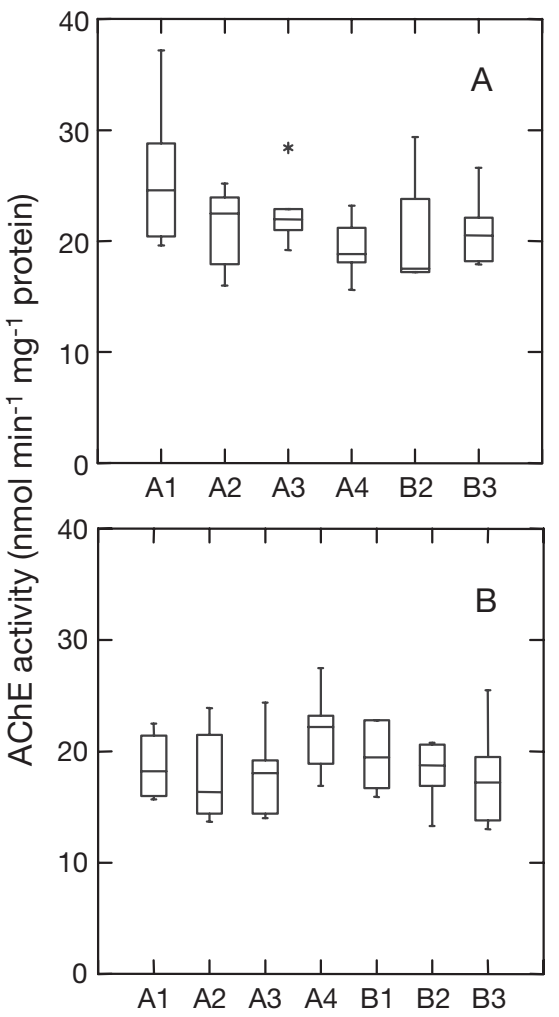

Fig. 2. Mytilus edulis, Macoma balthica. Box plots of acetylcholin esterase (AChE) activity in (A) gill tissue of $M$. edulis and (B) foot tissue of $M$. balthica at the study stations. Station codes as in Table 1. Each plot shows median, interquartile range, data range and mild $\left({ }^{*}\right)$ outliers for each station shown

MT

In the Tvärminne region, a gradient could be observed in the MT content of Mytilus edulis, with the highest values observed at Stn A1, closest to the Koverhar steel factory (mean and SE: $426 \pm 43 \mu \mathrm{g} \mathrm{g}^{-1}$ wet $\mathrm{wt}_{\text {; }}$ Fig. 3 , Table 2 ). The levels were significantly ( $\mathrm{p}$ $<0.05)$ lower at Stns A3 (303 $\pm 21 \mu g ~ g^{-1}$ wet wt) and A4 $\left(311 \pm 25 \mu \mathrm{g} \mathrm{g}^{-1}\right.$ wet $\left.\mathrm{wt}\right)$, furthest away from Koverhar. In Macoma balthica, no significant differences in MT levels between the stations in the Tvärminne region could be observed, with values ranging from 392 (A1) to $460 \mathrm{\mu g} \mathrm{g}^{-1}$ wet wt (A4). In the Turku region, somewhat higher MT levels were recorded in M. edulis collected at the northern Airisto Stn B1 $\left(405 \pm 24 \mu g^{-1}\right.$ wet wt) compared with the other ('reference') station sampled (B3; $345 \pm 38 \mu \mathrm{g} \mathrm{g}^{-1}$ wet wt), but the difference was not statistically significant. In M. balthica a 3station gradient was marked with the values observed at Stn B1 (542 $\pm 29{\mu g^{-1}}^{-1}$ wet wt) being significantly $(\mathrm{p}<0.01)$ higher than those recorded at Stn B3 $(414 \pm$ $27 \mathrm{\mu g} \mathrm{g}^{-1}$ wet wt). In general, the levels of MT were about $25 \%$ higher in $M$. balthica than in M. edulis. 
GST

In Mytilus edulis, the highest values for GST activity were recorded at the mid-transect Stn A3 in the Tvär-

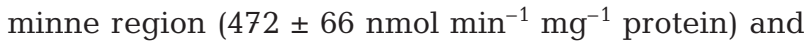

the reference Stn B3 in the Turku region (472 $\pm 19 \mathrm{nmol}$ $\mathrm{min}^{-1} \mathrm{mg}^{-1}$ protein; Fig. 4). The lowest activity was observed close to the Koverhar factory $(A 1 ; 339 \pm 34 \mathrm{nmol}$ $\mathrm{min}^{-1} \mathrm{mg}^{-1}$ protein). No statistically significant differences could be detected between the stations and the

Table 2. Mytilus edulis, Macoma balthica. Compilation of statistical analyses (ANOVA, post-hoc Tukey) on variability in biomarker responses of bivalves at different stations within different regions. ${ }^{*} \mathrm{p}<0.05 ;{ }^{* *} \mathrm{p}<0.01$; ns: not significant at $\mathrm{p} \geq 0.05$

\begin{tabular}{|c|c|c|c|c|c|c|}
\hline Study area & Species & Biomarker & $F$ & $\mathrm{p}$ & & Differing stations \\
\hline Tvärminne region & M. edulis & $\begin{array}{c}\mathrm{AChE} \\
\mathrm{MT} \\
\mathrm{GST} \\
\mathrm{CAT}\end{array}$ & $\begin{array}{l}2.410 \\
4.552 \\
1.385 \\
0.880\end{array}$ & $\begin{array}{l}0.097 \\
0.022 \\
0.264 \\
0.461\end{array}$ & $\begin{array}{c}\text { ns } \\
{ }^{*} \\
\text { ns } \\
\text { ns }\end{array}$ & A1 vs $\mathrm{A} 3$ and $\mathrm{A} 4: \mathrm{p}<0.05$ \\
\hline Turku region & M. edulis & $\begin{array}{c}\text { AChE } \\
\text { MT } \\
\text { GST } \\
\text { CAT }\end{array}$ & $\begin{array}{l}0.144 \\
1.219 \\
1.205 \\
0.117\end{array}$ & $\begin{array}{l}0.866 \\
0.311 \\
0.315 \\
0.890\end{array}$ & $\begin{array}{l}\text { ns } \\
\text { ns } \\
\text { ns } \\
\text { ns }\end{array}$ & \\
\hline Tvärminne region & M. balthica & $\begin{array}{c}\text { AChE } \\
\text { MT } \\
\text { GST } \\
\text { CAT }\end{array}$ & $\begin{array}{l}1.593 \\
2.262 \\
2.161 \\
1.073\end{array}$ & $\begin{array}{l}0.222 \\
0.118 \\
0.110 \\
0.373\end{array}$ & $\begin{array}{l}\text { ns } \\
\text { ns } \\
\text { ns } \\
\text { ns }\end{array}$ & \\
\hline Turku region & M. balthica & $\begin{array}{c}\text { AChE } \\
\text { MT } \\
\text { GST } \\
\text { CAT }\end{array}$ & $\begin{array}{l}0.399 \\
7.500 \\
6.597 \\
6.355\end{array}$ & $\begin{array}{l}0.678 \\
0.008 \\
0.005 \\
0.007\end{array}$ & $\begin{array}{l}\text { ns } \\
* * \\
* * \\
* *\end{array}$ & $\begin{array}{l}\text { B1 vs B3: } p<0.01 \\
\text { B1 vs B3: } p<0.01 \\
\text { B1 vs B2 and B3: } p<0.01\end{array}$ \\
\hline
\end{tabular}

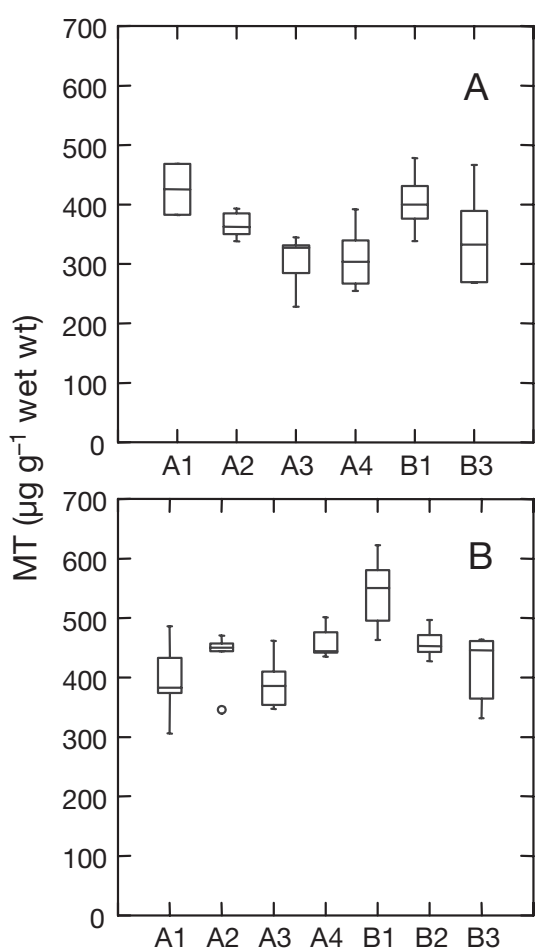

Fig. 3. Mytilus edulis, Macoma balthica. Box plots of metallothionein (MT) content in the digestive gland of (A) M. edulis and (B) $M$. balthica at the study stations. Station codes as in Table 1. Each plot shows median, interquartile range, data range and mild $\left(^{*}\right)$ and extreme $(0 ;>3.0 \times$ interquartile range) outliers for each station shown

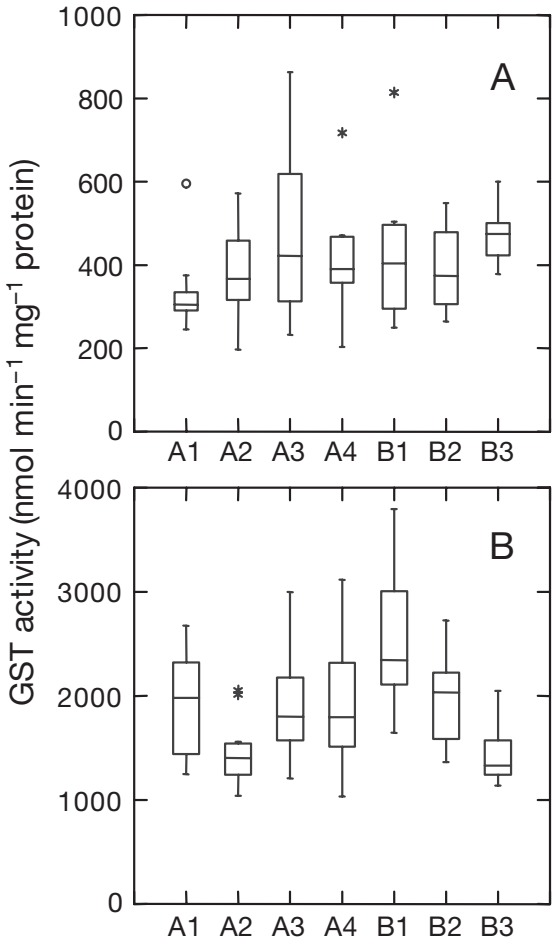

Fig. 4. Mytilus edulis, Macoma balthica. Box plots of glutathione S-transferase (GST) in the digestive gland of (A) $M$. edulis and (B) $M$. balthica at the study stations. Station codes as in Table 1. Note different scales. Each plot shows median, interquartile range, data range and mild $\left({ }^{*}\right)$ and extreme $(0$; $>3.0 \times$ interquartile range) outliers for each station shown 
regions (Table 2). In Macoma balthica, the values were similar at all stations of the Tvärminne region transect

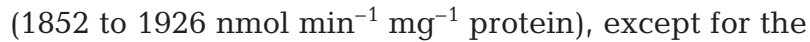
slightly lower activities recorded at Stn A2 (1467 \pm

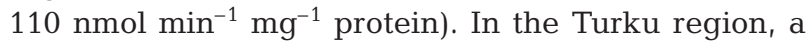
distinct gradient in GST activity was observed, with enzyme rates recorded at Stn B1 $\left(3078 \pm 543 \mathrm{nmol} \mathrm{min}^{-1}\right.$ $\mathrm{mg}^{-1}$ protein) twice as high compared with the refer-

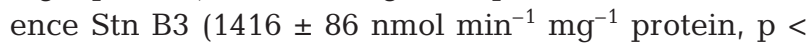
0.01). On average, the GST activity in $M$. balthica was ca. 5-fold higher compared with M. edulis.

\section{CAT}

In Mytilus edulis, no significant variability could be noted between the stations and the 2 study regions (Fig. 5, Table 2). Highest CAT activity was observed at the outermost station of the Tvärminne region (A4; $144 \pm 24 \mu \mathrm{mol} \mathrm{min}{ }^{-1} \mathrm{mg}^{-1}$ protein), while at all the other stations the activity was 105 to $125 \mu \mathrm{mol} \mathrm{min} \mathrm{mg}^{-1}$ protein. In Macoma balthica collected from the Tvärminne region, no statistically significant gradient in CAT activity could be observed either, with the lowest mean value recorded at Koverhar $(\mathrm{A} 1 ; 277 \pm 36 \mu \mathrm{mol}$

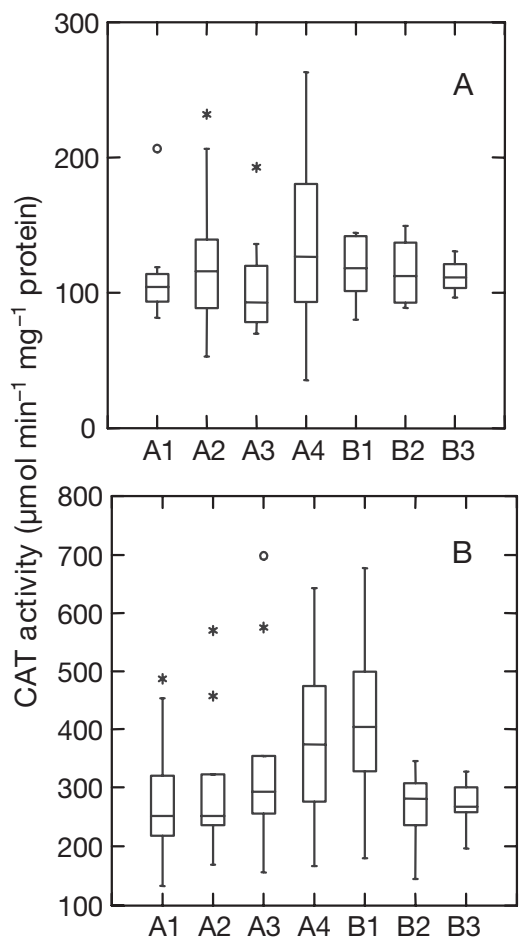

Fig. 5. Mytilus edulis, Macoma balthica. Box plots of catalase (CAT) activity in (A) M. edulis and (B) M. balthica at the study stations. Station codes as in Table 1. Note different scales. Each plot shows median, interquartile range, data range and mild $\left({ }^{*}\right)$ and extreme $(0 ;>3.0 \times$ interquartile range) outliers for each station shown $\mathrm{min}^{-1} \mathrm{mg}^{-1}$ protein) and highest in the open-sea region $\left(\mathrm{A} 4 ; 379 \pm 44 \mu \mathrm{mol} \mathrm{min} \mathrm{mg}^{-1}\right.$ protein). In the Turku region, a significant $(\mathrm{p}<0.01)$ gradient could be observed with the highest CAT activity at the northern Airisto

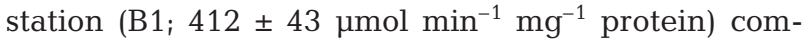
pared with the 2 other stations (B2 and B3) showing equal mean values $\left(270 \pm 20\right.$ and $269 \pm 22 \mu \mathrm{mol} \mathrm{min}^{-1}$ $\mathrm{mg}^{-1}$ protein, respectively). On average, CAT activity in M. balthica was ca. 2.5 times higher compared with $M$. edulis.

\section{Tissue pollutant levels}

\section{Organochlorines}

Analyses of organochlorines in the soft bodies of the bivalves showed marked gradients, especially in the Turku region (Table 3). The steepest gradient was observed in the case of $\Sigma$ PCBs (8 congeners), with the clearly highest values at Stn B1, both in Macoma balthica and Mytilus edulis (881 and $133 \mathrm{ng} \mathrm{g}^{-1}$ lipid, respectively), with congeners CB-153, CB-101, CB-149 and CB-138 forming ca. $90 \%$ of the $\Sigma$ PCBs. At the 'reference' Stn $B 3$ the respective $\Sigma$ PCB concentrations in the tissues were 249 and $60 \mathrm{ng} \mathrm{g}^{-1}$ lipid. A similar but less steep pattern could be observed in $\mathrm{DDDT}$ compounds with $M$. balthica and $M$. edulis at Stn B1 containing 217 and $83 \mathrm{ng} \mathrm{g}^{-1}$ lipid, respectively, and 130 and $56 \mathrm{ng} \mathrm{g}^{-1}$ lipid at Stn B3. In the Tvärminne region, homogeneous $\Sigma$ DDT concentrations (99 to $109 \mathrm{ng} \mathrm{g}^{-1}$ lipid) in the tissues of $M$. balthica were observed.

The DDT $\left(o, p^{\prime}\right.$-DDT $+p, p^{\prime}$-DDT) to $\Sigma$ DDTs (including metabolites) ratio showed marked variability, both between the species and the study regions (Fig. 6). In Mytilus edulis the ratios ranged from 7.5 to $12.0 \%$ in the Tvärminne region and between 39.1 and $42.3 \%$ in the Turku region, while in Macoma balthica the ranges were $2.3-3.8 \%$ and $8.1-13.2 \%$ in the respective areas.

If the organochlorine concentrations are expressed on a dry weight basis, the differences between the stations become somewhat smaller, due to the marked differences in tissue lipid levels (Table 4). In Macoma balthica the lowest lipid levels were recorded at Stns A4 and B1 (2.3\% of wet wt), while the highest value was recorded at Stn B2 (3.3\%). In Mytilus edulis a markedly low lipid level was observed at Stn A3 $(1.0 \%)$, with the others being between 1.7 and $3.4 \%$

\section{Heavy metals}

Tissue heavy metal concentrations showed marked interspecies variability, with Macoma balthica containing an order of magnitude higher levels of $\mathrm{Cu}$ and $\mathrm{Zn}$ 


\begin{tabular}{|c|c|c|}
\hline w $\stackrel{\stackrel{n}{\oplus}}{\circ}$ & 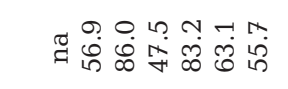 & 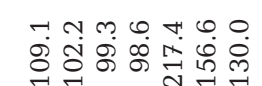 \\
\hline W & 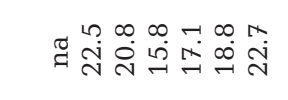 & 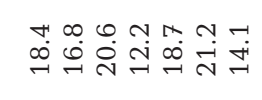 \\
\hline 它 & 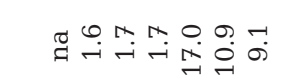 & 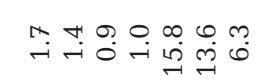 \\
\hline 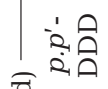 & 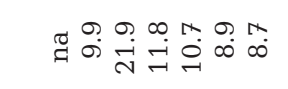 & 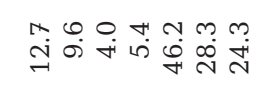 \\
\hline 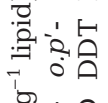 & 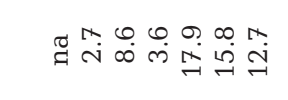 & 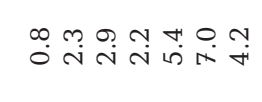 \\
\hline 兘客合 & 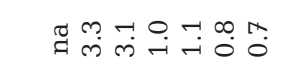 & 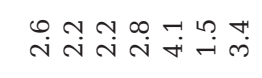 \\
\hline 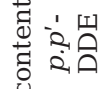 & 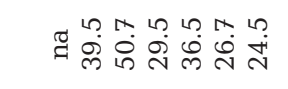 & 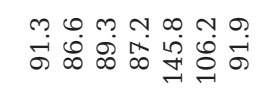 \\
\hline 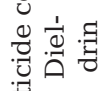 & 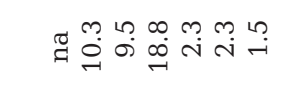 & 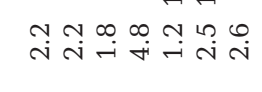 \\
\hline 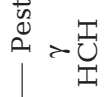 & 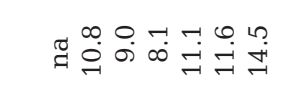 & 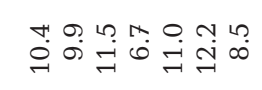 \\
\hline 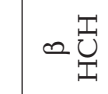 & 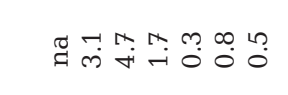 & 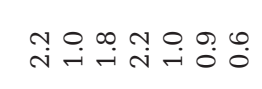 \\
\hline ૪焉 & 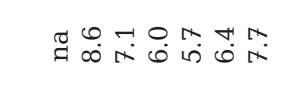 & 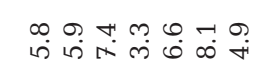 \\
\hline$\underbrace{\oplus}_{\text {U }}$ & 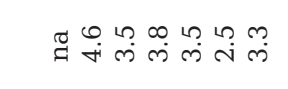 & 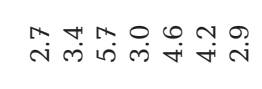 \\
\hline W ֶै & 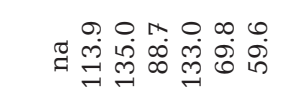 & 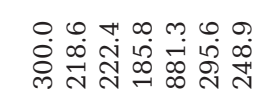 \\
\hline 艺 $\stackrel{\infty}{\infty}$ & 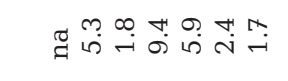 & 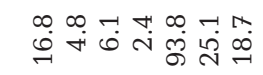 \\
\hline$\left.\right|_{\sigma} ^{\infty} \stackrel{\infty}{\sim}$ & 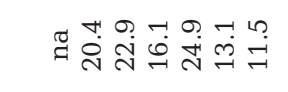 & 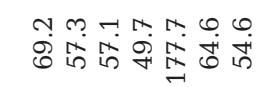 \\
\hline 承象 & 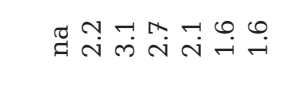 & 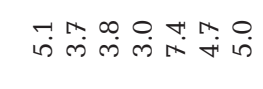 \\
\hline 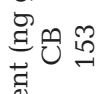 & 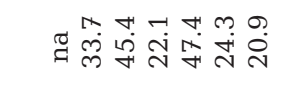 & 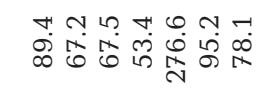 \\
\hline 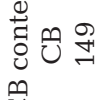 & 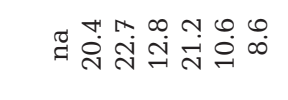 & 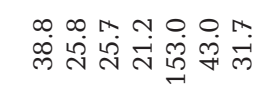 \\
\hline 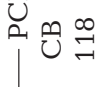 & 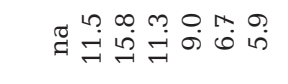 & 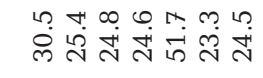 \\
\hline 己ૈ & 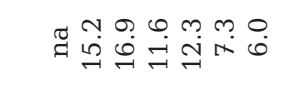 & 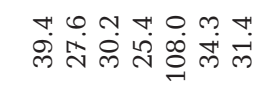 \\
\hline นै กิ & 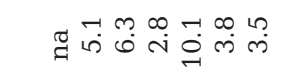 & 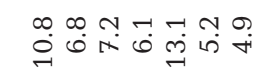 \\
\hline 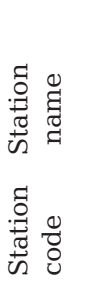 & 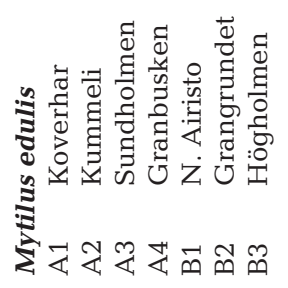 & 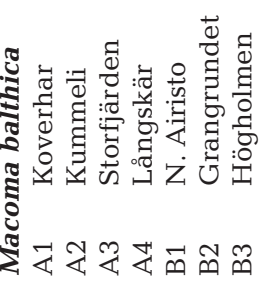 \\
\hline
\end{tabular}

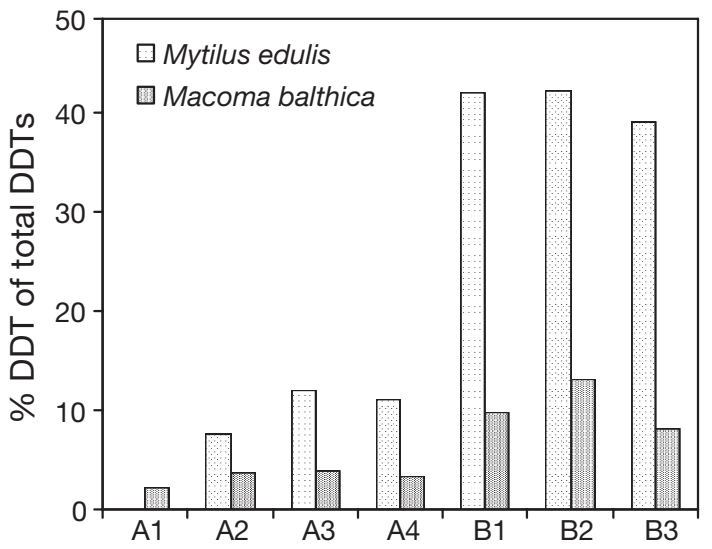

Fig. 6. Mytilus edulis, Macoma balthica. DDTs $\left(o, p^{\prime}\right.$-DDT + $p, p^{\prime}$-DDT) to total DDTs (all forms) ratio at the study stations. Station codes as in Table 1

compared with Mytilus edulis, which in turn had significantly higher levels of $\mathrm{Cd}$ (Table 5). The levels of Hg were similar in both species. In M. balthica, the values for $\mathrm{Cu}$ and especially $\mathrm{Zn}$ were distinctly higher in the Tvärminne region (694 to $1410 \mu \mathrm{g} \mathrm{g}^{-1}$ dry wt) compared with the Turku region (392 to $605 \mu^{-1} \mathrm{~g}^{-1}$ dry wt). With regard to $\mathrm{Zn}$, an apparent gradient was observed in both areas. In $M$. edulis, no significant variability between the main study areas could be noted.

\section{Integrated biomarker response index versus standardised pollutant levels}

In Macoma balthica the calculated IBR index indicated that the northern Airisto station (B1) was unquestionably the most contaminated site, with the IBR decreasing along the gradient (Fig. 7). Mytilus edulis at Stn B1 also displayed the highest IBR, but differences to the other stations were smaller.

Means of standardised organochlorines (PCBs + DDTs) in the tissues of Macoma balthica showed a clear gradient in the Turku region, with markedly higher values at Stn B1 (Fig. 7). In Mytilus edulis the picture was less clear, but the same station again emerged as the most polluted one.

In Macoma balthica, the mean of standardised tissue levels of $\mathrm{Cd}, \mathrm{Cu}, \mathrm{Hg}$ and $\mathrm{Zn}$ suggests that the overall 'metal stress' in the Tvärminne region was more or less equal regardless of station and much higher in general compared with the Turku region (Fig. 7). In Mytilus edulis no such trait could be seen; instead, Stn B1 again emerged as the most affected site.

In addition, normalised biomarker and tissue organochlorine levels in both species and sites combined showed significant linear regressions between total organochlorines and biomarkers $\left(n=12, \mathrm{r}^{2}=0.53, \mathrm{p}=\right.$ 
Table 4. Mytilus edulis and Macoma balthica. Dry wt \% and lipid levels (\% of wet wt) in pooled tissue samples subjected to organic pollutant analyses, and protein levels of different tissues, measured in connection with AChE, GST and CAT activity analyses. DG: digestive gland; -: not measured

\begin{tabular}{|c|c|c|c|c|c|c|c|}
\hline Species & $\begin{array}{l}\text { Station } \\
\text { code }\end{array}$ & $\begin{array}{l}\text { Station } \\
\text { name }\end{array}$ & $\begin{array}{l}\text { Dry wt (whole } \\
\text { tissue \% wet wt) }\end{array}$ & $\begin{array}{l}\text { Lipid (whole } \\
\text { tissue \% wet wt) }\end{array}$ & $\begin{array}{l}\text { Protein in DG } \\
\left(\mathrm{mg} \mathrm{ml}^{-1}\right), \mathrm{S} 9\end{array}$ & $\begin{array}{l}\text { Protein in gill } \\
\left(\mathrm{mg} \mathrm{ml}^{-1}\right), \text { S9 }\end{array}$ & $\begin{array}{l}\text { Protein in foot } \\
\left(\mathrm{mg} \mathrm{ml}^{-1}\right), \mathrm{S} 9\end{array}$ \\
\hline \multicolumn{8}{|c|}{ Mytilus edulis } \\
\hline & A1 & Koverhar & - & - & 12.0 & 4.4 & - \\
\hline & A2 & Kummeli & 12.0 & 2.2 & 9.6 & 4.8 & - \\
\hline & A3 & Sundholmen & 8.0 & 1.0 & 11.2 & 4.3 & - \\
\hline & A4 & Granbusken & 9.5 & 1.7 & 11.0 & 4.8 & - \\
\hline & B1 & N. Airisto & 13.7 & 2.5 & 13.1 & 4.8 & - \\
\hline & B2 & Grangrundet & 16.5 & 3.4 & 10.6 & - & - \\
\hline & B3 & Högholmen & 12.7 & 2.5 & 8.9 & 5.1 & - \\
\hline \multicolumn{8}{|c|}{ Macoma balthica } \\
\hline & A1 & Koverhar & 12.8 & 2.6 & 7.5 & - & 7.7 \\
\hline & $\mathrm{A} 2$ & Kummeli & 13.9 & 2.8 & 7.4 & - & 7.4 \\
\hline & A3 & Storfjärden & 14.5 & 2.9 & 6.9 & - & 9.5 \\
\hline & A4 & Långskär & 13.9 & 2.3 & 8.2 & - & 8.9 \\
\hline & B1 & N. Airisto & 14.3 & 2.3 & 6.0 & - & 6.4 \\
\hline & B2 & Grangrundet & 14.3 & 3.3 & 9.7 & - & 8.5 \\
\hline & B3 & Högholmen & 13.7 & 3.0 & 10.0 & - & 7.2 \\
\hline
\end{tabular}

Table 5. Mytilus edulis, Macoma balthica. Tissue levels of heavy metals at the study stations. -: not measured

\begin{tabular}{|c|c|c|c|c|c|}
\hline \multirow{2}{*}{$\begin{array}{l}\text { Station } \\
\text { code }\end{array}$} & \multirow{2}{*}{$\begin{array}{c}\text { Station } \\
\text { name }\end{array}$} & \multicolumn{4}{|c|}{ Tissue concentration $\left(\mu \mathrm{g} \mathrm{g}^{-1} \mathrm{dw}\right)$} \\
\hline & & $\mathrm{Cd}$ & $\mathrm{Cu}$ & $\mathrm{Hg}$ & $\mathrm{Zn}$ \\
\hline \multicolumn{6}{|c|}{ Mytilus edulis } \\
\hline $\mathrm{A} 1$ & Koverhar & 1.43 & 9.6 & 0.044 & 73.1 \\
\hline A2 & Kummeli & 1.93 & 10.4 & 0.021 & 94.7 \\
\hline A3 & Sundholmen & 2.42 & 10.3 & 0.017 & 88.6 \\
\hline A4 & Granbusken & 2.63 & 11.3 & 0.065 & 76.6 \\
\hline B1 & N. Airisto & 2.45 & 12.5 & 0.039 & 92.9 \\
\hline B2 & Grangrundet & - & - & - & - \\
\hline B3 & Högholmen & 2.56 & 10.5 & 0.024 & 78.9 \\
\hline \multicolumn{6}{|c|}{ Macoma balthica } \\
\hline A1 & Koverhar & 0.63 & 172.5 & 0.046 & 1410.0 \\
\hline A2 & Kummeli & 0.76 & 206.9 & 0.061 & 831.5 \\
\hline A3 & Storfjärden & 0.92 & 222.9 & 0.042 & 953.3 \\
\hline A4 & Långskär & 1.00 & 177.2 & 0.047 & 693.9 \\
\hline B1 & N. Airisto & 0.77 & 108.8 & 0.056 & 604.8 \\
\hline B2 & Grangrundet & 0.71 & 40.3 & 0.015 & 447.2 \\
\hline B3 & Högholmen & 0.32 & 79.8 & 0.070 & 391.7 \\
\hline
\end{tabular}

0.008), $\Sigma$ PCBs and biomarkers $\left(n=12, \mathrm{r}^{2}=0.58, \mathrm{p}=\right.$ $0.004)$, total organochlorines and GST activity and $\Sigma \mathrm{PCBs}$ and GST activity $\left(n=13, \mathrm{r}^{2}=0.64, \mathrm{p}=0.001\right.$, both cases). For heavy metals, Cd showed weaker but significant relationships with GST $\left(n=13, \mathrm{r}^{2}=0.32, \mathrm{p}=\right.$ $0.045)$ and CAT activities $\left(n=13, \mathrm{r}^{2}=0.33, \mathrm{p}=0.041\right)$.

\section{DISCUSSION}

\section{Chemical pollution and biomarker responses in the study regions}

The high proportion of parent DDTs (DDT to $\mathrm{DDDT}$ ratio) in tissues of both bivalve species collected from the Turku region indicates more recent inputs compared with the Tvärminne region. It is apparent that although not in active use anymore DDT is still circulating in the marine environment of this area and can therefore be found in unmetabolised and metabolised forms in both the sediments and the water phase, subsequently bioaccumulating in organisms. In the case of the Tvärminne region, the ratios of DDT to $\Sigma$ DDTs show that, at present, DDT released into the environment decades ago is substantially 'used up' and increasingly found in the environment in metabolised forms, as DDDs and DDEs. However, with regard to biological effects, the poor correlations observed between biomarker responses and tissue levels of DDTs suggest that there is no direct relationship. With regard to PCBs, despite the fact that elevated levels were observed especially at Stn B1, some other, unmeasured anthropogenic substances potentially present at this station situated close to a former dumping site of harbour dredging waste can play a part in the impacts observed. Thus, the levels of organochlorines measured here should rather be taken as proxies of the level of general anthropogenic pollution at the different sites, not necessarily as the direct causes of the observed responses.

Macoma balthica from the Tvärminne region contains markedly higher amounts of $\mathrm{Cd}, \mathrm{Cu}$ and $\mathrm{Zn}$ compared with those inhabiting the Turku region. The impact of the large Koverhar steel factory, present since the 1950s, although with significantly reduced pollutant release in recent years, can still be observed in terms of high levels of certain metals in the tissues of clams. Tissue concentration of $\mathrm{Zn}$ at the Koverhar station (1440 $\mu \mathrm{g} \mathrm{g}^{-1}$ dry wt) was strikingly high compared with other observations in the Baltic Sea (e.g. 


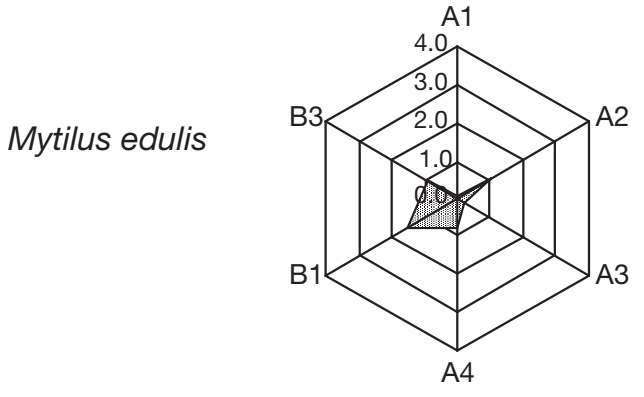

IBR

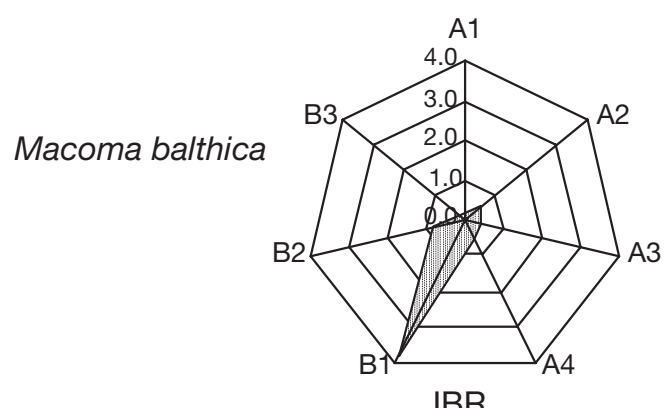

IBR

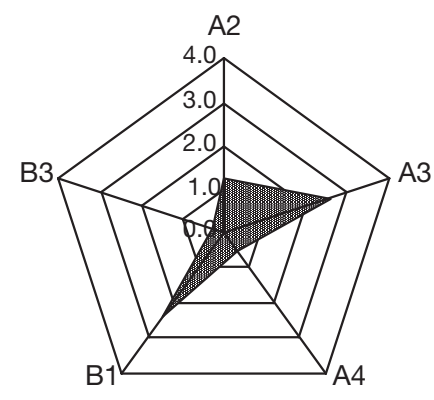

OCs

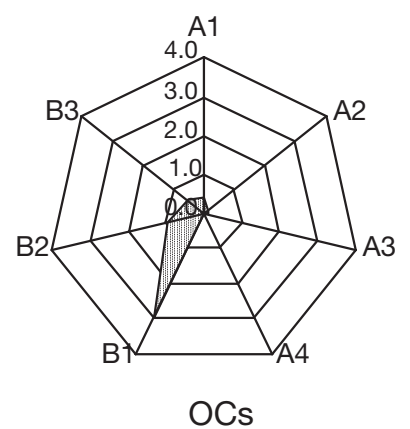

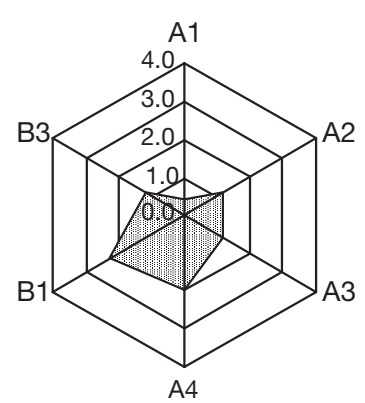

HMs

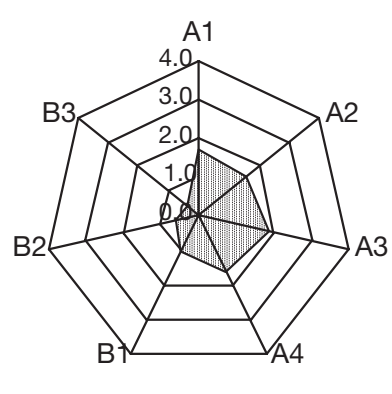

HMs

Fig. 7. Mytilus edulis, Macoma balthica. Starplot graphics on integrated biomarker response (IBR) index calculated from 4 biomarkers (AChE, MT, GST and CAT), and mean values of standardised data of 8 PCB congeners and DDTs (organochlorines [OCs]) and 4 heavy metals ( $\mathrm{Cd}, \mathrm{Cu}, \mathrm{Hg}$ and $\mathrm{Zn}[\mathrm{HMs}])$ at the study stations. Original chemical data is found in Tables 3 \& 5. Station codes as in Table 1. Please note the missing stations with regard to M. edulis due to the lack of chemical data

Jankovski et al. 1996). Regoli et al. (1998) recorded levels of $\mathrm{Cd}$ between ca. 0.18 and $0.55 \mu \mathrm{g} \mathrm{g}^{-1}$ dry wt, of $\mathrm{Cu}$ between ca. 13 and $37 \mu \mathrm{g} \mathrm{g}^{-1}$ dry wt and of Zn between 200 and $700 \mathrm{\mu g} \mathrm{g} \mathrm{g}^{-1}$ dry wt in M. balthica collected from several bays in the Russian Arctic. In the Tvärminne region the ranges for $\mathrm{Cd}$ and $\mathrm{Zn}$ are about twice as high, while the $\mathrm{Cu}$ levels are around 10-fold higher. In contrast to the other metals studied, the concentrations of $\mathrm{Cd}$ are markedly higher in Mytilus edulis compared with $M$. balthica. Studies by Lee et al. (1998) confirm that $M$. balthica is a good indicator of the accumulation of $\mathrm{Zn}$, while $\mathrm{Cd}$ accumulates to a much lesser extent. In M. edulis, even higher Cd concentrations $\left(4.05 \mu \mathrm{g} \mathrm{g}{ }^{-1}\right.$ dry wt) have been recorded (Jankovski et al. 1996) in the Estonian part of the Gulf of Finland. In general, metal levels in bivalve tissues found here are within the ranges measured in these areas before (Kaitala 1981, Itkonen et al. 1998, Korhonen et al. 2001) and cannot be considered alarmingly high compared with observations in other sea areas.

However, Macoma balthica showed higher MT levels at Stn B1 in the Turku region compared with the stations in the Tvärminne region. In addition to binding by MTs, partitioning to metal-rich microgranules may play an important role in promoting metal tolerance of populations inhabiting sediments with elevated metal concentrations (Brown 1982, Klerks \&
Weis 1987, Ballan-Dufrançais et al. 2001, Wallace et al. 2003). Apart from metals, there may also be other chemical stressors inducing MT formation at Stn B1 (see discussion below). In any case, when the 2 regions are compared, the content of MT in M. balthica does not appear to be always related to the tissue loads of metals.

Marked gradients observed in GST and CAT activity in Macoma balthica in the Turku region indicate that, at Stn B1, the presence of elevated chemical contamination intensifies phase II conjugation mechanisms and enhances hydrogen peroxide elimination related to the oxidative stress complex. The increased CAT signal may also be related to the elevated levels of MT, since these proteins are also a part of the antioxidant defence system (Viarengo et al. 2000). In vertebrates, the MT gene has been shown to be induced under prooxidant conditions (Dalton et al. 1996). In rainbow trout, activation of MT gene transcription by hydrogen peroxide, the substrate of CAT, has been demonstrated (Olsson et al. 1995). However, since the production of reactive oxygen species (ROS) is strongly linked to cytochrome P-450 induction, which in mussels (Mytilus spp.) is only about $1 \%$ of that found in mammals, it has been argued that exposure to organic pollutants and MT induction through subsequent ROS production is not a significant process in mussels (Viarengo et al. 
1999). Nevertheless, other ROS-producing detoxification pathways not mediated by P-450s may be in operation. In this study, the data on organic contaminants in the soft tissues of $M$. balthica with marked gradients in PCBs and DDTs in the Turku region corresponds well with the gradients observed in the levels of GST, CAT and MT in the same area. This implies that detoxification reactions and metabolic responses to oxidative stress may be caused by the catabolism of organic xenobiotics.

The observed interspecies differences, with Macoma balthica expressing 3- to 4-fold (CAT) and 7- to 8-fold (GST) higher enzyme activities in comparison with Mytilus edulis, most likely do not only represent species-characteristic ecological levels but also mirror the observed tissue loads of organic contaminants, which in the sediment-dwelling $M$. balthica are on average 2fold (DDTs) or 3-fold (PCBs) higher than in M. edulis. Compared with $M$. edulis, $M$. balthica showed markedly higher tissue accumulation of $\mathrm{Cu}, \mathrm{Zn}$, PCBs and DDTs, whereas the levels of Cd were higher in $M$. edulis. Interspecies variability in MT levels was apparent, with 1.5 -fold lower values in $M$. edulis compared with $M$. balthica, as observed by Lehtonen \& Leiniö (2003). This is probably due to the fact that $M$. balthica lives within soft sediments and is mostly a deposit feeder, thus being constantly exposed to pollutants deposited in organic particles of sediments that it feeds on, as well as soluble pollutants in interstitial water. Being a suspension feeder, $M$. edulis is exposed to considerably lower levels of pollutants in the suspended particulate matter or soluble compounds present in seawater. Besides biological differences in uptake kinetics, the difference may be due to the sedimentdwelling lifestyle of $M$. balthica, which raises its exposure to, for example, bioavailable metals in both their physical environment (hypoxic/anoxic sediment layers, pore water) and food items. In addition, metabolic differences between the species could also play an important role in the observed differences in tissue pollutant levels between the species.

Finally, with regard to the observed homogeneity in the levels of AChE activity the results obtained here confirm the view that organophosphate/carbamate pesticides are not an environmental problem in Finnish coastal waters. Other chemical stressors that can cause AChE-coupled neurotoxic effects do not appear to be present in effective concentrations.

\section{Application of biomarkers in the Baltic Sea}

Among many other specific characteristics of the Baltic Sea, the constant low-salinity environment $(<6.5$ in Finnish coastal waters) creates physiological stress to marine species that may affect biomarker responses. Thus, basic information on the levels of biomarker responses and their natural variations is needed prior to the application of these techniques and use of these species in monitoring of pollutant-induced biological effects in the Baltic Sea ecosystem. Information is needed not only on the effects of potentially confounding factors such as eutrophication and the resulting hypoxic conditions in the near-bottom waters (commonly observed e.g. in the Gulf of Finland), but also on the physiological adaptations of species inhabiting these areas.

Mytilus edulis is a marine species able to penetrate into brackish environments; however, many of its physiological, morphological and growth characteristics are distinctively modified in the Baltic Sea (e.g. Kautsky et al. 1990, Tedengren et al. 1990). The lowsalinity stress is extreme in the northern part of the Baltic, where the distribution of $M$. edulis comes to an end at salinities <4.5 (Lassig 1965). Therefore, concerning this species some precautions should be taken in the interpretation of biomarker data when comparing the responses observed in northern Baltic Sea populations to those inhabiting more saline southern regions (up to ca. 15) or fully marine environments. With regard to Macoma balthica, populations thrive in the Baltic Sea down to a salinity of 2 (Lassig 1965) if other main environmental factors such as sediment type, dissolved oxygen content of near-bottom water, food supply and water depth are suitable. Compared with mussels, $M$. balthica is physiologically much better adapted to the conditions prevailing, for example, in the Gulf of Finland, and the responses observed in the present study are thus more comparable with those measured in other areas of the species' wide distribution.

Salinity can have an effect on the 'baseline' levels of biomarkers, as potentially is the case with MT. In Mytilus edulis, a gradient in MT levels was observed in the Tvärminne region, while the average levels did not differ from those recorded in the Turku region. No gradients could be observed in the tissue levels of metals, nor were the mean levels different between the areas. When examined together with the results obtained during the Baltic Sea component of the BEEP project, the mean MT level in M. edulis was observed to elevate by about 2 -fold towards the north, seemingly along the salinity gradient (Leiniö \& Lehtonen 2005, Baršienè et al. 2006, Kopecka et al. 2006, Schiedek et al. 2006, this study). Concerning Macoma balthica, the only data available on MT levels in the southern Baltic Sea also suggest salinity-related signal levels: a mean

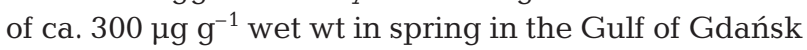
(BEEP project, unpubl. data) is markedly lower compared with the average value of $442 \mu \mathrm{g} \mathrm{g}^{-1}$ wet wt obtained in the present study. The higher MT levels 
might be connected to chemical speciation of certain metals resulting in higher bioavailability in low-saline environments (e.g. M. balthica: Lee et al. 1998). On the other hand, in the Russian Arctic no significant effect of salinity on the MT level of either species could be observed (Amiard-Triquet et al. 1998). In some cases, changes in general protein metabolism caused by natural factors have been shown to modulate MT content more than metal accumulation in tissues (Legras et al. 2000). Since MT levels exhibit a marked natural oscillation during the year in both species in the study region (Leiniö \& Lehtonen 2005) and also elsewhere (e.g. Bordin et al. 1997), food conditions and reproductive stage must also be considered when interpreting the data (e.g. Mourgaud et al. 2002). The extensive seasonal variability in temperature in the northern Baltic Sea also affects the reproductive cycle of marine organisms, potentially having a marked effect on various biomarker responses (Leiniö \& Lehtonen 2005). Regardless of the cause, the level of the MT induction was highest in the present study area compared withthe other Baltic Sea areas studied.

\section{Integrated biomarker response approach}

The use of integrated biomarker indices is a relatively new approach in the marine ecotoxicological context (Adams et al. 1993, Narbonne et al. 1999, Beliaeff \& Burgeot 2002, Chèvre al. 2003a,b, Broeg \& Lehtonen 2006). Integrating the numerical measures of a set of biological signals that reflect malfunctions or, potentially, a decreased performance in organisms into a single index has advantages considering the rough evaluation of the 'pollution status' of marine populations or environments which they inhabit. Chemical analyses can only show the concentrations of single contaminants in the environment, while an integrated biomarker index demonstrates also their bioavailability, interactive effect and combined effects. Since comparing areas with highly differing environmental characteristics that govern bioavailability and biological effects of different pollutants usually allows only very limited conclusions, a rational way is to treat the systems as a whole, i.e. using integrated response approaches that demonstrate more complex in situ signals in populations at each particular site. The IBR index used in this study merged the comparative information obtained from 4 biomarkers, and the value obtained this way related distinctively to the concentrations of tissue organochlorine residues measured at the most contaminated site in comparison with the other sites. The use of an integrated biological measure is of practical importance when examining, for example, temporal developments along different suspected pollution gradients or comparing different geographical regions.
As our results show, this approach also has high potential in detecting biological effects along comparatively small-range contamination gradients.

\section{CONCLUSIONS}

The results obtained indicate a pollution gradient in the Turku region, identified both by measurements of selected biomarker responses in bivalves and by concentrations of selected pollutants in their tissues. The gradient was clearly indicated in the sedimentdwelling Macoma balthica, while the suspension-feeding Mytilus edulis showed a more ambiguous distribution of tissue pollutants and biomarker responses. In the Tvärminne region such an obvious gradient was not detected, although variability in pollutant levels and biomarker signals between the stations was observed. Overall, the Turku region appears to be much more affected by organic anthropogenic pollutants, while the Tvärminne region is characterised by a higher load of heavy metals.

This study is the first of its kind performed in the coastal waters of Finland. The results obtained demonstrate the usefulness of the multibiomarker approach, including the integrated biomarker response index. Using 2 sessile species with markedly differing feeding modes, living habitats and, therefore, routes of exposure to environmental pollutants is considered a rational strategy for assessing the pollution status of coastal sea areas. Using an integrated response measure, one can detect possible synergistic effects of different compound groups (e.g. organochlorines and heavy metals) that might remain hidden if only one biomarker was used. Regarding the species studied, the infaunal, softsediment clam Macoma balthica appears an increasingly promising organism for biological-effects monitoring in the northern Baltic Sea.

Acknowledgements. Tvärminne Zoological Station (University of Helsinki) and Archipelago Research Station (University of Turku) are thanked for assistance in sampling. Dr. P. Mora (University of Bordeaux I) is thanked for advice on GST and CAT activity measurements and Ms. M. Kronholm for testing of the protocols in the early phase of the project. U. Karlström (MSc) assisted in the analyses. Ms. S. Lage and Mr. J. Riikonen skilfully executed the organochlorine and metal analyses, respectively. We thank Dr. D. Schiedek for editorial suggestions on the final version of the manuscript.

\section{LITERATURE CITED}

Adams SM, Brown AM, Goede RW (1993) A quantitative health assessment index for rapid evaluation of fish condition in the field. Trans Am Fish Soc 122:63-73 
Amiard-Triquet C, Rainglet F, Larroux C, Regoli F, Hummel H (1998) Metallothioneins in Arctic bivalves. Ecotoxicol Environ Saf 41:96-102

Ballan-Dufrançais C, Jeantet AY, Geffard A, Amiard JC, Amiard-Triquet $C$ (2001) Cellular and tissular distribution of copper in an intrasedimentary bivalve, the Baltic clam Macoma balthica, originating from a clean or a metal-rich site. Can J Fish Aquat Sci 58:1964-1974

Baršienè J, Lehtonen KK, Koehler A, Broeg K and 9 others (2006) Biomarker responses in flounder (Platichthys flesus) and mussel (Mytilus edulis) in the Klaipèda-Būtingè area (Baltic Sea). Mar Pollut Bull (in press)

Beliaeff B, Burgeot T (2002) Integrated biomarker response (IBR): a useful graphical tool for ecological risk assessment. Environ Toxicol Chem 21:1316-1322

Bocquené G, Galgani F (1998) Biological effects of contaminants: cholinesterase inhibition by organophosphate and carbamate compounds. ICES Tech Mar Environ Sci 22. ICES, Copenhagen

Bordin G, McCourt J, Cordeiro Raposo F, Rodriguez AR (1997) Metallothionein-like metalloproteins in the Baltic clam Macoma balthica: seasonal variations and induction upon metal exposure. Mar Biol 129:453-463

Bradford MM (1976) A rapid and sensitive method for quantitation of microgram quantities of protein utilizing the principle of protein dye binding. Anal Biochem 72:248-254

Broeg K, Lehtonen KK (2006) Indices for the assessment of environmental pollution of the Baltic Sea coasts: integrated assessment of a multi-biomarker approach. Mar Pollut Bull (in press)

Brown BE (1982) The form and function of metal-containing 'granules' in invertebrate tissues. Biol Rev 57:621-667

Chèvre N, Gagné F, Blaise C (2003a) Development of a biomarker-based index for assessing the ecotoxic potential of aquatic sites. Biomarkers 8:287-298

Chèvre N, Gagné F, Gagnon P, Blaise C (2003b) Application of rough sets analysis to identify polluted aquatic sites based on a battery of biomarkers: a comparison with classical methods. Chemosphere 51:13-23

Claiborne A (1985) Catalase activity. In: Greenwald RA (eds) Handbook of methods for oxygen radical research. CRC Press, Boca Raton, FL, p 283-284

Dalton TP, Li Q, Bittel D, Liang L, Andrews GK (1996) Oxidative stress activates metal-responsive transcription factor1 binding activity. J Biol Chem 271:26233-26241

Day KE, Scott IM (1990) Use of acetylcholinesterase activity to detect sublethal toxicity in stream invertebrates exposed to low concentrations of organophosphate insecticides. Aquat Toxicol 18:101-114

Di Giulio RT, Wasburn PC, Wenning RJ, Winston GW, Jewell CS (1989) Biochemical responses in aquatic animals: a review of determinants of oxidative stress. Environ Toxicol Chem 8:1103-1123

Ellman GL, Courtney KO, Andrres V, Featherstone RM (1961) A new and rapid colorimetric determination of acetylcholinesterase activity. Biochem Pharmacol 7:88-95

George SG, Olsson PE (1994) Metallothioneins as indicators of trace metal pollution. In: Kramer KJM (ed) Biomonitoring of coastal waters and estuaries. CRC Press, Boca Raton, FL, p 151-178

Grasshoff K (1983) Methods of seawater analysis, 2nd edn. Verlag Chemie, Weinheim

Habig WH, Pabst MJ, Jakoby B (1974) Glutathione-S-transferase. The first enzymatic step in mercapturic acid formation. J Biol Chem 249:7130-7139

Holden AV, Marsden K (1969) Single-stage clean up of animal tissue extracts for organochlorine residue analysis. J Chromatogr 44:481-492
IAEA (Innternational Atomic Energy Agency) (1980) Progress report on intercalibration of organochlorine compound measurements in marine environmental samples. Report No. 2, International Laboratory of Marine Radioactivity, Musée Oceanographique, Monaco

IAEA (Innternational Atomic Energy Agency) (1988) Final report om the intercomparison of organochlorine compounds in shrimp homogenate (MA-A-3/OC) and on fish homogenate (MA-B-3/OC). Report No. 37, International Laboratory of Marine Radioactivity, Musée Oceanographique, Monaco

Itkonen A, Vahteri P, Wright J, Vuorinen I (1998) Ruoppausmassojen läjittämisen vaikutukset vesistöön ja kalatalouteen Pohjois-Airistolla. Raportti vuonna 1997 tehdyistä tutkimuksista. Archipelago Research Institute, University of Turku (in Finnish)

Jankovski H, Simm M, Roots O (1996) Harmful substances in the ecosystem of the Gulf of Finland. Part I. Trace metals. EMI Rep Ser 4:1-158

Kaitala S (1981) Simpukoiden raskasmetallipitoisuuksista Suomen rannikkovesissä. Meri 9:120-146 (in Finnish)

Kautsky N, Johannesson K, Tedengren M (1990) Genotypic and phenotypic differences between Baltic and North Sea populations of Mytilus edulis evaluated through reciprocal transplantations. I. Growth and morphology. Mar Ecol Prog Ser 59:203-210

Klerks PL, Weis JS (1987) Genetic adaptation to heavy metals in aquatic organisms: a review. Environ Pollut 45:173-205

Kopecka J, Lehtonen KK, Baršienò J, Broeg K, Vuorinen PJ, Gercken J, Balk L, Pempkowiak J (2006) Measurements of biomarker levels in flounder (Platichthys flesus) and blue mussel (Mytilus trossulus) from the Gulf of Gdańsk (Southern Baltic). Mar Pollut Bull (in press)

Korhonen M, Verta M, Backström V (2001) Harmful substances. In: Kauppila P, Bäck S (eds) The state of Finnish coastal waters in the 1990s. The Finnish Environment 472. Finnish Environment Institute, Helsinki

Lassig J (1965) The distribution of marine and brackish-water lamellibranchs in the northern Baltic area. Commentat Biol 28:1-41

Lee BG, Wallace WG, Luoma SN (1998) Uptake and loss kinetics of $\mathrm{Cd}, \mathrm{Cr}$ and $\mathrm{Zn}$ in the bivalves Potamocorbula amurensis and Macoma balthica: effects of size and salinity. Mar Ecol Prog Ser 175:177-189

Lee RF, Keeran WS, Pickwell GV (1988) Marine invertebrate glutathione-S-transferase: purification, characterisation and induction. Mar Environ Res 24:97-100

Legras S, Mouneyrac C, Amiard JC, Amiard-Triquet C, Rainbow PS (2000) Changes in metallothionein concentrations in response to variation in natural factors (salinity, sex, weight) and metal contamination in crabs from a metalrich estuary. J Exp Mar Biol Ecol 246:259-279

Lehtonen KK, Leiniö S (2003) Effects of exposure to copper and malathion on metallothionein levels and acetylcholinesterase activity of the mussel Mytilus edulis and the clam Macoma balthica from the northern Baltic Sea. Bull Environ Contam Toxicol 71:489-496

Lehtonen KK, Schiedek D (2006) Monitoring biological effects of pollution in the Baltic Sea: neglected - but still wanted? Mar Pollut Bull (in press)

Leiniö S, Lehtonen KK (2005) Seasonal variability in biomarkers in the bivalves Mytilus edulis and Macoma balthica from the northern Baltic Sea. Comp Biochem Physiol C 140:408-421

Mourgaud Y, Martinez E, Geffard A, Andral B, Stanisiere JY, Amiard JC (2002) Metallothionein concentration in the mussel Mytilus galloprovincialis as a biomarker of 
response to metal contamination: validation in the field. Biomarkers 7:479-490

Narbonne JF, Daubeze M, Clerandeau C, Garrigues P (1999) Scale of classification based on biochemical markers in mussels: application to pollution monitoring in European coasts. Biomarkers 4:415-424

Olsson PE, Kling P, Erkell LJ, Kille P (1995) Stuctural and functional analysis of the rainbow trout (Oncorrhynchus mykiss) metallothionein-A gene. Eur J Biochem 230:344-349

Rainbow PS, Phillips DJH (1993) Cosmopolitan biomonitors of trace metals. Mar Pollut Bull 26:593-601

Regoli F, Hummel H, Amiard-Triquet C, Larroux C, Sukhotin A (1998). Trace metals and variations of antioxidant enzymes in Arctic bivalve populations. Arch Environ Contam Toxicol 35:594-601

Schiedek D, Broeg K, Baršienò J, Lehtonen KK and 7 others (2006) Biomarker responses and indication of contaminant effects in blue mussel (Mytilus edulis) and eelpout (Zoarces viviparus) from the western Baltic Sea. Mar Pollut Bull (in press)

Schneider R (1982) Polychlorinated biphenyls in cod tissues from the Western Baltic: significance of equilibrium parti-

Editorial responsibility: Otto Kinne (Editor-in-Chief), Oldendorf/Luhe, Germany tioning and lipid composition in the bioaccumulation of lipophilic pollutants in gill-breathing animals. Meeresforschung 29:69-79

Tedengren M, Andre C, Johannesson K, Kautsky N (1990) Genotypic and phenotypic differences between Baltic and North Sea populations of Mytilus edulis evaluated through reciprocal transplantations. III. Physiology. Mar Ecol Prog Ser 59:221-227

Viarengo A, Ponzano E, Dondero F, Fabbri R (1997) A simple spectrophotometric method for metallothionein evaluation in marine organisms: an application to Mediterranean and Antarctic molluscs. Mar Environ Res 44:69-84

Viarengo A, Burlano B, Dondero F, Marro A, Fabbro R (1999) Metallothionein as a tool in biomonitoring programmes. Biomarkers 4:455-466

Viarengo A, Burlando B, Ceratto N, Panfoli I (2000) Antioxidant role of metallothioneins: a comparative overview. Cell Mol Biol 46:407-417

Wallace WG, Lee BG, Luoma SN (2003) Subcellular compartmentalization of $\mathrm{Cd}$ and $\mathrm{Zn}$ in two bivalves. I. Significance of metal-sensitive fractions (MSF) and biologically detoxified metal (BDM). Mar Ecol Prog Ser 249:183-197

Submitted: June 2, 2004; Accepted: March 2, 2006

Proofs received from author(s): August 30, 2006 